\title{
Transposition
}

Musique et Sciences Sociales

\section{9| 2021}

Musique et sexualité

\section{La Petite Mort: Techniques of Orgasm in Electronic Dance Music}

La Petite Mort : techniques d'orgasme dans l'Electronic Dance Music

\section{Toby Young}

\section{(2) OpenEdition \\ 1 Journals}

\section{Electronic version}

URL: http://journals.openedition.org/transposition/6024

DOI: 10.4000/transposition.6024

ISSN: 2110-6134

\section{Publisher}

CRAL - Centre de recherche sur les arts et le langage

\section{Electronic reference}

Toby Young, "La Petite Mort: Techniques of Orgasm in Electronic Dance Music", Transposition [Online], 9 | 2021, Online since 15 March 2021, connection on 23 April 2021. URL: http://

journals.openedition.org/transposition/6024 ; DOI: https://doi.org/10.4000/transposition.6024

This text was automatically generated on 23 April 2021.

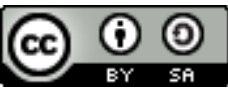

La revue Transposition est mise à disposition selon les termes de la Licence Creative Commons Attribution - Partage dans les Mêmes Conditions 4.0 International. 


\title{
La Petite Mort: Techniques of Orgasm in Electronic Dance Music
}

\author{
La Petite Mort : techniques d'orgasme dans l'Electronic Dance Music
}

Toby Young

\section{AUTHOR'S NOTE}

This project was generously funded by Carolyn and Franco Gianturco as part of a Junior Research Fellowship at Linacre College, Oxford, with additional support from the Lucy Halsall Fund. I am extremely grateful to the friends and colleagues who provided invaluable comments and suggestions on early drafts, particularly Cayenna PonchioneBailey, and to the research participants for their time and insights.

1 In a provocative online video from 2014 entitled When Will the Bass Drop?,1 comedy powerhouse Saturday Night Live mocks Electronic Dance Music (EDM) culture's obsession with achieving a musical climax. In a witty take on questions of authenticity, performativity and stardom, protagonist DJ Davvincii (Andy Samberg) employs nearly every stereotypical trope of EDM build-up to work a dancefloor full of adoring fans into a frenzy of arousal and anticipation. As Samberg plays games on his laptop, cooks an egg, and assembles a model railway set - a collection of ridiculously mundane acts - the libidinous energy of the dancefloor builds to breaking point, as participants writhe in increasing extreme and orgiastic embodiment of the music's pounding sexuality. Just when the sexual intensity of the grinding bodies and flailing limbs of the participants gets almost too much for viewer to bear, Samberg drops the eponymous bass, accompanied by a voiceover cameo from rapper Lil Jon inviting him to "turn up to death". Screams and moans of ecstasy are heard from participants as the camera pans round the dancefloor in slow motion, as the intense climax makes clubbers heads explode, blowing their bodily loads on the dancefloor in one of the most literal ways possible. 
2 It is hardly surprising that the semiotic associations between the rise and fall of a DJ set depicted by SNL and the libidinous cycles of intercourse have become the subject of many discussions of dance music. From within its careful building of energy and tension, the semiotic play of EDM's musical erotics arouses sexual activity in participants, while in turn affecting the club environment to help the sonic intercourse become all the more visceral and embodied. Musically, the intense, pulsating beats and of climaxes and plateaus of EDM - a genre characterised by regular, repeated kick drum beats (known as "four to the floor") at speeds ranging between about 120 and 160 beats per minute - is intended to instigate sexually-charged and intimate bodily movements on the dancefloor and more explicit acts being enacted in dark corners of a club. ${ }^{2}$ Cycles of energy and interaction reflect this sexual energy activity back to voyeuristic DJ in their chaste position of observation ${ }^{3}$ : as they deftly manipulate their equipment with virtuosity and skill, the DJ enacts the role of a sex worker, teasing participants through an alternation of musical build-ups, charged with semiotic expectation, and careful denials of pleasure intended to keep the dancefloor on the brink of orgasm. Finally, when the DJ feels the sexual tension has been pushed as far as it will go, a visceral musical shift or turning point ("the drop") brings participants to a euphoric release of energy, often described in the literature as a profound spiritual experience of revelation and ecstasy. ${ }^{4}$

3 As can be seen in the SNL clip, there is something about the sensual intensity of a nightclub - described by Graham St John as "the kinaesthetic maelstrom of the dance floor"5 - that facilitates everything from uninhibited expressions of intimacy to full on orgiastic abandon amongst participants. With surprising similarity to a porn film, the dancing mass utter collective sexual vocalisations ranging from grunts to screams and facial expressions of ecstasy - two of the distinct affective displays of orgasm - strongly suggesting that they are remembering, recognizing, and reliving the experience, or at least ecstasy, of past or imagined sexual experiences. To paraphrase Paul Morris and Susanna Paasonen's discussion on the virtual experience of pornography, "the 'somatic archives' of our bodies [i.e. our compiled memories of skills, experiences, and sensations] facilitate bridging the sensory gaps between the sexual acts seen and heard and those experienced in the flesh, while the rhythms and intensities [of the music, in this case]... help to bridge them further". ${ }^{6}$ From out of their haptic memories, the participants' bodies resonate with the carnal narrative of the music, moving up and down in time to the intimate mediation of the music. But in a paradox central to thinking sexually about EDM, the (semi)public space ${ }^{7}$ within which club-space sits typically prohibits participants from engaging in explicit sexual activity, save from maybe kissing and dry humping. If we are not intended to literally climax, how can we explain the highly sexualised narratives of fulfilment at the heart of EDM communities: is this music designed to convey how sex looks and sounds devoid of the feeling of real arousal; a simulacrum perhaps for unachievable fleshy sensations? Are the sexualised narratives a schema for participants to make sense of the complex, hyperstimulated sensory experience of clubbing? Or is it literally intended to make participants come?

\section{Sonic Foreplay}

4 The impetus for this study came during previous work on the aesthetic conception of beauty amongst dance music producers and consumers, where I interviewed 67 
participants (a total of 40 men and 27 women) across three locations in the UK, all playing the same specially curated set lists of music. During data collection, participants responded to a questionnaire that included several open-ended questions relating to their experiences of both their musical and social practices of the night. During thematic analysis, I noticed an overwhelming number of participants used metaphors of orgasm or sexual pleasure to describe their clubbing experiences, making me curious to reflect on the interrelationship of sexual imagery and the club experience. In this article, by disentangling the language of sex from both the experience of clubbing and the vernacular discourse surrounding it (i.e. through the construction of metaphors) I hope to better understand whether these sexualised listening strategies emerge from real synchrony with the clubbing experience, and if so, how these narratives feedback into dance music culture to further orient participants' perceptual manifolds.

5 We begin, of course, by setting the mood. An almost universal observation amongst participants (mentioned by $87 \%$ of the interviewees) was that the club space sets the scene for a sexualised musical listening. Isabella (29, female) noted that,

[a]way from the hustle and bustle of the city streets, there's something about the dark basement vibe that's intimate, even sexy. You, like, go down this long, black corridor towards the thumping at the end, and emerge into this intense stimulation of lights, sounds, sweaty bodies [laughs]... I mean, how can that not be sexual?!

Many commentators have likened clubspace to a Foucauldian heterotopia: ${ }^{8}$ a nocturnal safe space (the so-called "temporary autonomous zone") outside the rhythms and expectations of everyday society, where participants are invited to perform fantasy versions of themselves. In the words of Jean-Luc Nancy, "[a]t night, one enters into another space, less visible but denser, into another time, too. Time doesn't pass in the same way, which induces a special rhythm to the sexual act, even though we don't only make love at night". ${ }^{9}$ Alongside the bright strobe lighting, loud pulsating music (often experienced as much through bone conduction as aural penetration) and extreme haptic stimulus of the close proximity of sweaty bodies and sexually suggestive dancing described by Isabella, participants frequently choose to enhance the intense sensory intensity of this extra-ordinary space through the use of illegal drugs. These drugs typically ecstasy or amphetamines - not only alter the phenomenological quality of the musical listening experience but also the inhibitions and expectations that frame participants' engagements with each other. ${ }^{10}$ The reasons for participation in EDM events varies, but the hedonistic search for an ecstatic, embodied pleasure is high on many clubbers agendas. There were, however, a few outliers such as Giorgio (34, male).

It's clear most people are just here to find someone to fuck later. I hate that to be honest. When you feel people are just hunting among the crowd for a sexual mate rather than actually appreciating the music.

7 With its focus on bodily interaction, the nightclub is a unique listening environment. Whilst a value of the haptic takes clear predominance over the aural for most interviewees, Giorgio's connoisseurship, loaded with the privilege of cultural capital, reminds us that of the multiplicity of values and practices amongst participants: a pluralism too often forgotten by academic work in this area. In Giorgio's comment we see a tension between those who go clubbing as an embodied means of musical consumption and those that see the space as a precursor to intercourse. This preparation occurred in two ways for participants: one being the 'selection space', and the other being the use of EDM's penetratingly loud and repetitive music and its 
enaction on the body to (literally and metaphorically) warm up participants for more traditional carnal activities which may ensue. As several participants noted with various levels of poeticism, the hot and sticky intimacy of a nightclub serves to 'get you in the mood' for fucking. One participant, Leon (30, male), highlighted that it was not only the intense physicality of the club setting that set the scene for sexual activity.

I can't be the only one to hear this music as basically a porn soundtrack, am I? I mean come on - you have this low thumping under the whole thing, and then these sort of moany noises [imitates synth sound] over the top which totally sound like some porn actress about to come.

8 It is perhaps not surprising that neurologically the optimal auditory landscape for sexual activity is noises which mirror the sexual mate, based on cues during intercourse "ranging from gross movements, to vocal signals, to subtle patterns of emotional expression". ${ }^{11}$ The sonic quality of EDM plays a crucial role in the mediation and creation of sexual intensity, with many tracks invoking grunts, heavy breathing and bodies slamming through the producer's choice of instrumental sounds or use of the throbbing swells of sidechain compression. The production of EDM is comparable to the soundtracks to porn films in many ways: immediate and direct mixing with emphasis on an intimacy of sonic attack to ensure that the "sonorous envelope... come[s] up close in order to enfold the viewer". ${ }^{12}$ Even the instruments used in many of the more popular EDM styles (whose producers often fetishise the drum machines and electronic instruments rooted in disco) allude to the generic conventions of the porn music - "from the 1970s porn funk to 1980s synthesizer soundscapes"13 - which are no doubt familiar to many. Where lyrical content is included (often in female, rather than male voices), the words uttered are spontaneous expressions of pleasure, with sounds recorded close to the source, often intimately so, and typically either with breathy or harsh onsets to create visceral, animalistic vocalisations.

9 Much of the work of a DJ during a club night is invested in facilitating bodily engagement through auditory means; one of the most important tools for this being the repeated rhythm of EDM's kick drum. With orgasms resulting predominantly "from rhythmic stimulation of body parts with high concentrations of sensory receptors", ${ }^{14}$ enacting the regularized patterns of intercourse through muscular oscillations creates a distinctly sexual resonance. Like the masturbator synchronising their hand movements to the repetitive acts of bodies in porn, the entrainment between bodies and a respective aural stimulus causes the coupling of mechanical and neuronal oscillatory systems, creating a deepened sense of connection, synchronicity and absorption between participants; an ideal state for the sexual experience. ${ }^{15}$ As Adam Safron notes,

Music and dance may be the only things that come close to sexual interaction in their power to entrain neural rhythms and produce sensory absorption and trance... the reasons we enjoy sexual experiences may overlap heavily with the reasons we enjoy musical experience, both in terms of proximate (i.e. neural entrainment and induction of trance-like states) and ultimate (i.e. mate choice and bonding) levels of causation. ${ }^{16}$

Beyond just simple rhythmic stimulation though, the rich multi-modality of the entrainment on the dancefloor - sonically, visually and haptically - mirrors the "multiple potential channels for entrainment of an individual nervous system" that are triggered during sex. ${ }^{17}$ As the musico-sexual act progresses, this interconnectedness magnifies the feeling of intimacy in the club space, drawing participants into a 
different kind of proximity with both the music (a sort of oneness often described in terms of religious transcendence $\left.{ }^{18}\right)$ and their fellow clubbers. As Sarah (24, female) observes,

you're dancing to that thumping bass whilst grinding against some randomer, but it's kind of, like, not weird anymore [?]. It's like you're in this trance, and just dancing and dancing and everyone's all so familiar and friendly [...] [and] suddenly the gross musky club smell becomes kind of hot, and you feel like everyone's in it together, you know?

\section{I'm Comiiiiing!}

11 There have been too many accounts in EDM literature (and indeed musicology more generally) to paraphrase here, both for and against the teleological notion of a 'drive to climax' in music. ${ }^{19}$ It is perhaps sufficient enough to note here that it seems universal in both academic and colloquial accounts that a musical representation of orgasm is typically associated with the feeling of arrival, or climax. The build-up to discharge in an EDM pre-chorus typically employs as many musical devices as possible to mirror the final moments of accumulation before both male and female orgasm, where the rush to orgasm is physiologically denoted by increasing blood pressure, heart rate and rhythmic respiratory patterns,$^{20}$ whilst on the whole maintaining a regular pulse (perhaps speeding up a small amount). As with intercourse, musical energy gain is not achieved through accelerated speed, but rather a suite of alternative signifiers. Musical risers - the collective name for a variety of sonic effects comprising slowly rising tones, often accompanied by filter sweeps or arpeggiators to enhance their dynamic motion are perhaps the primary vehicle for this increase in momentum.

Like aural precum, these effects signal the growing intensity of the musical soundtrack, simulating a sort of cyborgian groaning of the technological sex partner with whom participants are invited to musically copulate. A faster rate of sonic and motivic change may be employed to add to the increasing intensity (i.e. the fast switching between sounds and musical ideas), whilst the addition of audio production effects like reverb, echoes, and floor-shaking sub-tones mirror the biological symptom of sensory dislocation caused by increased blood-flow to the genitals and away from the brain. In the final moments before the drop, automated snare rolls stutter with rapidly increasing speed and the pitch reaches its highest point; briefly stopping in anticipation of the climax, before a reintroduction of the beat and bass "drops" the sonic space down from the previously upward movements like a rollercoaster ride. Although many of the contributors to this study used sexual imagery to describe this moment of release, Monica's (27, female) description is definitely the most explicit.

The build-up and release of [the DJ] was completely unreal! I totally wasn't expecting it, but the music kept on growing and growing... and then the music dropped and it was like, 'I'm comiiiiing!' [laughs].

13 The drop is one of the primary modes through which the DJ can mediate the crowd's affective and bodily energies. Whether well-versed in EDM structure or not, participants cannot but be led instinctively by the overwhelming mass of building signifiers as the build-up reaches its "maximum energy potential" and the drop becomes "inevitable". ${ }^{21}$ The moment of suspense at this peak before the arrival marks a moment of a communal moment of desire, pulling the clubspace together in the shared suspense of group expectation before "going wild... by all dancing together in this 
massive moment of ecstasy" (Leon), often with auditory additions such as exclamatory screams and more energetic and engaged use of arm and hand movements. In addition to satisfying the psychological condition of arrival and fulfilment required by the orgasming subject rather well, the rhetorical function of the drop seems to have a similar correspondence with the physiological manifestations of orgasm: particularly an increase in energy and stamina during ejaculation and the sensation of muscular spasm (typically of the genitals and anus) experienced as involuntary body movements. ${ }^{22}$ As James (26, male) observes,

When the DJ drops the beat and everyone goes wild, it's like we suddenly are all in it together... [as] a big mass of bodies and limbs.

Monique Charles's description of the drop as "an organisation of sounds... [intended] to usher momentary communitas into liminal space" ${ }^{23}$ feels particularly apt here, with the coming together of multiple partners in a shared moment of ecstasy - both literally and metaphorically - being one of the main biological and social goals of sex..$^{24}$ As Simon Reynolds notes, clubspace is one of community and connection ${ }^{25}$, where interconnectivity and openness is often enhanced by participants through the imbibing of narcotics like MDMA. As well as suppressing inhibition, the addition of ecstasy (and similar substances) in the blood stream increases the brain's release of Dopamine - the neurochemical responsible for the experience of reward and pleasure - which occurs naturally for participants during both an orgasm and musical climax, ${ }^{26}$ dramatically increasing "pleasurable feelings to the point of ecstasy". ${ }^{27}$ In a group situation, the level of reward is notably enhanced by the feedback loop of shared experience, ${ }^{28}$ creating a "strange and wondrous atmosphere of collective intimacy" between complete strangers. ${ }^{29}$ As nearly all of the interviewees in this study noted, it is almost impossible to not attend to the "in the moment" experience of community that this sense of shared release creates, with many highlighting the shared sense of consciousness that this collective focus on enjoyment and euphoria affords.

\section{Multiplicities of Representation}

One of the most surprising features of the data was many of the participant's reliance on androcentric imagery to describe their experiences. For nearly all of the interviewees in this study, the tangible, visual narrative of the (male) orgasm - with its point of ejaculatory climax - seemed to provide the most accessible metaphor for their experiences of ecstasy, even if this did not necessarily equate to their own bodily knowledge of orgasm. Only one participant specifically talked in terms of female orgasm, and even then, this was through a recollection of Bernini's statue The Ecstasy of Saint Teresa, rather than a comparative account with her own sexual experiences. In reality though, the overwhelming masculinisation of narratives and metaphors from the data is perhaps not that surprising. Ever since early representation of orgasms in film and music (around the 1960s and early 1970s), female orgasm was "either overlooked or assimilated to that of the male... [whereas the] different rhythms and temporalities of a woman's pleasure were simply not acknowledged" ${ }^{30}$ Even today, journalism often seems to maintain the rhythms of male ejaculation as a shorthand for discussion of orgasm and sexual fulfilment. ${ }^{31}$ Where it does appear, scholarship on female sexual experience within music largely focuses on the quality and volume of orgasmic vocalizations ${ }^{32}$ rather than more comprehensive and holistic representations 
of sexual pleasure, whilst the music industry focus only on women conforming to masculine ideas of pleasure by '“ejaculating' through moaning and making noise, thrashing and performing as sexually excited... rather than [focussing on] pleasure in general". ${ }^{33}$

When we push the metaphor of the male orgasm beyond a basic build-up and arrival/ release schema, it soon becomes apparent that it does not stand up to scrutiny in describing the experience of ecstasy at the moment of a drop. For a start, an EDM track typically has multiple points of climax in a representation far more similar to the female experience of orgasm rather than a clear, single moment of arrival. As Rae Langton notes, unlike men, "many women have [...] the desire and capacity for more than one orgasm, without a significant break [...] a capacity linked to the fact that all women tend, after orgasm, to return to the so-called "plateau" phase of excitement, rather than the pre-aroused state (as men do)". ${ }^{34}$ Flows between and through these different states of pleasure are crucial to understanding female experiences of ecstasy and climax.

The female orgasmic pleasure in particular is not a local excitement that stays in the area of stimulation, however intense it may be; it is an eruption of enjoyment that spreads throughout the whole experiencing body. Pleasure springs from sensuous sources but then traverses in a cumulating or explosive manner literally from head to toe. Moreover, when sensuous pleasure reaches the peak of jouissance, the wave of orgasm carries itself forward without any additional stimulus or catalyst..$^{35}$

As a genre built on closed harmonic loops and underpinned by monotonous, rhythmic repetition, dance music relies on slow, shifting cycles of transition rather than clearly linear development. Where for many scholars, teleological models of pleasure "insufficiently explain affective engagement with groove-based music", ${ }^{36}$ this is not to say that there cannot be accumulation towards certain points: indeed, the drop can only exist as the result of these "recombinant teleologies", as Robert Fink terms them, ${ }^{37}$ which bring together repetition and teleology into a symbiotic hybridity of layered directionality. As Maria Witek notes, the gradual introduction and removal of sonic material in EDM gives the listener '“aural cues' that invite [them]... to shift their attention within the dense texture of overlapping layers, allowing them to create their own 'sonic pathways"' through the music, ${ }^{38}$ but these pathways are not necessarily intended to reach a climax. In other words, instead of focusing on being "turned on" and "turned off", the layering of sonic elements of EDM invite us to focus on the "possibilities of heightened sensual energy as a tool to cultivate a continuous state of

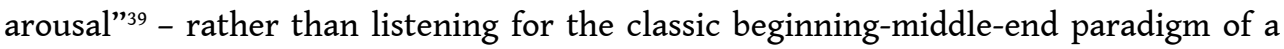
teleological structure - but within these heightened states, directionality and arrival can be distinguished by the shifts of energy and density between the plateaued states. Just like accounts of the female orgasm, pleasure in EDM therefore "arises from the process itself, rather than the process' results" ${ }^{40}$ But this reading sits at considerable odds with the cumshot directionality of the male orgasmic narrative and invites us to further unpick the role of arrival within the conflicting interpretations. Even accounting for the variance between sub-genres of dance music - with mainstream EDM relying a lot more heavily on narratives of intensity and arrival than other, more minimal genres, of dance music (e.g. techno, acid house and various forms of bass music) - the drop is a key semiotic tool across nearly all genres of dance music; ${ }^{41}$ yet 
how can we reconcile its immediate directionality with the processual accounts of Witek and Fink?

On the one hand, as already outlined, the drop marks a clear point of fulfilment from the preceding energy gain, releasing participants from a position of heightened tension and expectation to a state of euphoric release. But crucially there is another possible way to read this moment: not as an occasion of arrival but a point of removal, of restarting. After the onslaught of sonic battery experienced during the preceding build-up, with layer upon layer of musical material being compressed and superimposed upon itself, the typical shift to bass and bass drum is accompanied by an elimination of the higher pitched, intricate and/or "human" sonic layers (melodic content, vocal samples, etc.), mirroring a similar removal of higher-level cognition in favour of more base - and literally here, bass - levels of perception experienced during an orgasmic high. ${ }^{42}$ In other words, even in the most typically masculinised genres of EDM (such as the commonly-derided "brostep"), where musical structures are perhaps more explicitly formed around the male orgasm template ${ }^{43}$ the mechanism of climax that sits at the heart of nearly every EDM track (either overtly or covertly) is paradoxically both one of fulfilment and negation.

\section{An Alternative Reading}

Whilst going through the rhetorical gestures of climax over and over again, there is an aura of sexual tension that builds: orgasm is always close but never fully allowed to arrive. Like orgasm itself, this sensation is both a bodily sensation and a culturally coded semiotic act, meaning that the act of denial and release occurs at both the physical and cognitive levels. These power dynamics of control are outlined by Ragnhild Torvanger Solberg, who describes how

[the build-up] continues until the dance floor is bursting with anticipation and seemingly cannot tolerate this any longer. Yet, the DJ plays with them and pushes their boundaries of patience just a little further, before giving them the timely tension-resolving part. The bass and bass drum are dropped down, and the main groove returns with its regular rhythmic and melodic structures, ideally leaving the dance floor more ecstatic than ever. ${ }^{44}$

One important point to note here is that the figure of the DJ is (musically) chaste, "teasing" the crowd from their position of removal in the DJ booth rather than experiencing the collective ecstasy as an equal partner. While they perhaps might offer the occasional token participation - the odd dance move or vocal whoop here and there - they are not explicitly part of the libidinous network of enjoyment that is created between the sound (in both its sonic and haptic forms) and the participants. Conversely the club floor - the collective object of this musical fucking - is fully involved in the sexual act but has no real agency over how the experience will unfold. They are being made to come when, and how, the DJ wants, whether that be to tease the crowd through playful denial (but giving in eventually) or even to remove stimulation at the last moment for a ruined orgasm; as in an infamous YouTube video of a DJ who "trolled the crowd" by dropping a Spandau Ballet ballad at the climax of a high-energy buildup. ${ }^{45}$

21 By altering our focus from a model of orgasm-as-arrival to one of orgasm control and power play, we open up a fertile thread to unpick politics of orgasm in EDM. One set of 
erotic practices where this sort of control-play is central is BDSM (the acronym for Bondage/discipline, Dominance/submission, Sadism and Machoism). This comparison actually does not present us with too far of a theoretical leap. Kink has a long and enmeshed relationship with dance music, and indeed a large number of significant spaces in the genre's history (such as Berghain or KitKatClub in Berlin) are explicitly fetish clubs. Within the dungeon-like heterotopia of a darkened, underground basement, and beyond the restraint of quotidian society, participants in subspace are invited to abandon their prudishness and live out their fantasies within the anonymity of a "denaturalized sexual environment" 46 that is closely comparable to the notion of clubspace outlined earlier. Not only are participants encouraged to simply "be deviant", but they are explicitly afforded a safe space in the confines of a nightclub, where a literally and metaphorical insulation from the "real" world outside allows participants a freedom to experiment with alternative subjectivities. In BDSM, this play space (called the "scene") is used to recode "familiar and mundane experiences of power, relationships and intimacy [...] [in] a transformative, active process of engaging with the world and re-imagining, tweaking or recreating it". ${ }^{47}$ In other words the construction of an alternative world - perhaps through the performance of an alternative persona - creatively mediates between the internal self and the external world, mirroring the self-making practices of participants across a number of clubbased subcultures ${ }^{48}$ for whom a mediation of the social world is both pleasurable and, more often than not, political.

One particular self-making practice is the submission scene. This ritual is outlined in a didactic framework on the BDSM community blog Slave Nano designed to "lead to the complete submission of a slave to his/her mistress or master" ${ }^{49}$ The following excerpt outlines some of the key activities undertaken by the master and the slave (using the pseudonyms of Hindu Goddess Shakti and her male consort Shiva) during this rite:

Initiation Presentation - Shiva offers himself to Kali.

Supplication - Shiva surrenders his mind and body to Kali, taking up a supplicant position (kneeling, lying on his front, etc.)

Cleansing - Rituals around purifying body and mind before other activities take place involving water, fire - hot wax treatment or any other use of candles - or medical play.

Restraint - Shiva gives up control of his body to Kali.

Humiliation - Kali manipulates Shiva however she desires for her own pleasure and amusement. This could take the form of either mental or physical humiliation (e.g. through strap on play, watersports, food play, breath control or mental humiliation).

Surrender - This is the point where Kali has completely taken control of Shiva, both physically and mentally. The point of surrender will be a meaningful point in the rite of passage for both participants as it signals both Kali's exercise of dominance and also Shiva's willingness to open himself to her.

Climax - This is where Shiva reaches a point of crisis, brought about by extreme physical pain through punishment and torture or mental anguish. Release or orgasm might form part of this but only with Kali's approval. This will be an intense phase of the encounter between Kali and Shiva as a cathartic emotional release is reached for her slave.

Transformation - A very intense experience, which is likely to be the culmination of several of the different stages in the ritual, often repeated more than once. Thus differs from the climax described above in that it will have a spiritual and transformative element to it. 

night. As soon as the participant enters clubspace (presenting themselves for transformation) they are placed in a position of physical supplication to the DJ, raised up and distanced from the dancefloor like a shaman or deity..$^{50}$ With the intense sensual stimulus of loud music, bright, strobing lights and extreme physical intimacy, participants are focus on their present consciousnesses and cleansed from thoughts and distractions from the "real" world, before "giving up" their bodies to the hard, rhythmic drive of the music. As they surrender to instinctual and embodied dancing, the DJ is able to manifests their "complete control" over participants, controlling the musical narrative in ways already described that "use or abuse" the supplicated dancefloor for their amusement. Climax might form part of this, but only at the DJ's will, causing great cathartic release: true transformation however only occurs after multiple repetitions of this ritual..$^{51}$ As with dance music, the collective intimacy and vulnerability at the heart of the BDSM practice forms an emotional narrative from individual "desire, anticipation and excitement" to "shared group-dynamic feelings... of joining, love, affection [and] fellowship". ${ }^{52}$ The common focus and a supportive group dynamic of both scenarios instils a deep and long-lasting sense of belonging in participants, which facilitates community-building and motivates them to repeat the ritual.

There is a performative materialism of the BDSM, which - like the orgasm - links bodies in a way which questions our subjectivities, desires, and social relations. BDSM reminds us that desire need not be located within notions of transcendent states, but can be enacted through rituals, enmeshing the real and the metaphorical in ways which help us comment, critique, and expand the otherwise private experience of heteronormative sex in a public space by shifting what normally occurs inside the body during sex, outside the body. As Anna-Elena Pääkkölä notes,

Sex to a sadomasochist is not penetrative (necessarily), repetitive, or mundane. The whole body is seen as an erogenous zone, and consequently the experience of sexual gratification is more complex than exclusively genital-oriented sex. Sex organs can even go unstimulated during SM sex, and orgasms can still be achieved [...] sex is broadened to a state of mind, not an act. ${ }^{53}$

By making climax blatantly visible - moving beyond configurations of a genitalised, procreation-directed experience to a state of suspended time and space - the sadomasochist is also able to mobilise and critique larger-scale power relations and differentials in new and interesting ways that challenge and play with the dominant sexual organization. Crucially, by shifting the model from one of orgasm to one of catharsis, the BDSM narrative of orgasm helps us to reread the problematically male narratives of arrival (i.e. giving in to pleasure of orgasm) as kink-queered narratives of climax and transcendence. Just like the dancefloor, the masochist is ultimately in control of the fantasy in their mind, whatever the external power relations seem to imply, but paradoxically it is only by giving in to the extreme sonic and haptic intensity of the dancefloor that the subject is able to transcend the rigid barriers of social selfhood towards the ecstatic experience of emancipation often described in EDM literature. ${ }^{54}$

Transposition, 9 | 2021 


\section{Conclusions}

rhetoric of dance music with an orgasm is initially compelling, and seemingly brought to the fore in participants' minds by the social function of a nightclub as a place to attract sexual partners. The growing body of research into the orgasm's role as a "facilitator of pair bonding and social bonds" 55 - which, aside from its central role in the "classical training" of reproduction (i.e. the bodily reward of biologically useful behaviour), is now commonly believed to be its main function - highlights that both orgasms and EDM offer similar mechanisms of mediating social intimacy, and might therefore offer a productive dialogue in their respective means of achieving this shared function. However, where in some cases an invocation of satisfaction might offer a valuable tool to unpick the complex hermeneutic circle of sex which flows in club space (works by Chris Christodoulou, Hillegonda Rietveld and Luis-Manuel Garcia come to mind in particular), too often the narratives of orgasmic fulfilment that are brought into play become a musicological crux for researchers. In other words, it is important to remember in a discussion such as this one that a musical climax does not necessitate a sexual one.

Nevertheless, there is significant overlap between the two. As we have seen, the main work of sexualised listening to (or experiencing of) EDM-as-orgasm is to try and "understand and capture what the flesh is saying", ${ }^{56}$ to mediate the intensity and immediacy of the body in its enhanced state of physical pleasure. As the sonic and haptic sensations encoded in dance music' sensual timbral richness and clear narrative arcs of arrival and fulfilment resonate with the participants archives of bodily knowledge (as discussed earlier) to trigger arousal through the memories of sensations and situations that they call upon, often resulting in physiological stimulation. It is also possible that experiences of consuming music in this highly hedonistic and intimate way even serve to "shape and influence one's contingent somatic reservoirs" for the future.$^{57}$ Just as a connection between the music's overwhelming thud and these bodily sensations of sexual stimulation are semiotically fused in the participant's imagination, so these "musically transformed" archives might in turn position future ways of hearing and making sense of music within a sexualised framework.

Through this process of reinforcement and reconfiguring, musico-orgasmic listening is able to facilitate a form of sexual "self-making" in participants, helping us (in a DeNorian way) to construct and reflect our identities and practices as sexual beings. Beyond basic signification of sexual identity politics, music "propels our bodies to act in ways that may inform or enhance a sexual response [...] even affect[ing] sexual arousal and the accomplishment of sexual gratification". ${ }^{58}$ Considering EDM's role in developing sexual self-knowledge (re)connects us with dance music's origins as a predominantly queer scene, which "enabled young men [...] opportunities to inform and express their identities and their sexuality beyond the homophobic world of 'straights", ${ }^{59}$ and gave queer musicians and producers a platform to musically depict their own sexual stories in a safe space away from the judgement and fear of judgement. It is important to note though that beyond this underlying message of liberation lies one of sadness, since, for many LGBT communities threatened by AIDS and tragically restricted from intimacy, "jacking their bodies in furious sexual pantomime" became the most physically gratifying alternative to sex. ${ }^{60}$ 
It would be easy to draw an overly positive conclusion to this article by falling into a "straightforward" narrative of synthesis, whereby the uniquely musico-haptic space of EDM offers a freedom of sexual multiplicity that invites subjects to experience sexualised pleasure on their own terms; able to co-exist in an uncomplicated heterotopian transcendence of the rigid binaries of day-to-day life. In reality of course, no such "happy ending" exists. But in its place, I hope that a kinked re-thinking of the EDM climax might act as a call for musicologists to celebrate the potential for feminist and queer readings of musico-orgasmic listening that engage meaningfully with the tensions between extant literature and colloquial discourse. This is not to say that teleological approaches need be completely dismissed in this research, as seems to be increasingly common. Without negating the phallus' need to climax, the ambiguity of direction within this process-driven music creates a space for feminist and queered narratives to be heard as clearly as their androcentric counterparts when listening (and dancing) sexually to EDM. But equally the lens of fetishism presented at the end of this article offers an alternative goal-driven model through which to read the seemingly male-dominated data. Using the master/mistress-slave relationship as an alternative representation of the male orgasm model helps us to reclaim a goal-driven reading from heteronormative sexualisation, in deference to dance music's origins as a culture "shaped by the efforts of marginalized peoples to construct a space where they can feel important". ${ }^{61}$ Just like these queer spaces, BDSM "has the capacity to challenge or queer sexual and social norms" ${ }^{2}$ by being more explicit and visual about different types of sexual experiences both within and through musicking practices. There is definitely more work to be done here.

\section{BIBLIOGRAPHY}

BANCROFT J., “The endocrinology of sexual arousal”, The Journal of Endocrinology, vol. 186, no. 3, 2005, pp. 411-427.

BDSM Rituals: A description of a rite of passage into servitude / Slave Nano, http://slavenano.co.uk/ free-reads/bdsm-rituals-a-description-of-a-rite-of-passage-into-servitude/, accessed on 30 March 2020.

BLINNE Kristen C, “Auto(erotic)ethnography”, Sexualities, vol. 15, no. 8, 2012, pp. 953-977.

Burning Down the House: Read SPIN's 1986 Feature on Chicago's Club Scene / SPIN, https:// www.spin.com/2014/04/burning-down-the-house-chicago-club-80s/, accessed on 25 March 2020. BUTLER Mark, Unlocking the Groove: Rhythm, Meter, and Musical Design in Electronic Dance Music, Indiana University Press, 2006.

CARLSTRÖM Charlotta, “BDSM, Interaction Rituals and Open Bodies”, Sexuality \& Culture, vol. 22, no. 1, 2018, pp. 209-219.

CHARLES Monique, “Grime and Spirit: On a Hype!”, Open Cultural Studies, vol. 3, no. 1, 2019, pp. 107125. 
DENORA Tia, "Music and Erotic Agency - Sonic Resources and Social-Sexual Action", Body \& Society, 2016, https://journals.sagepub.com/doi/10.1177/1357034X97003002004.

DUNN Kate M., CHERKAS Lynn F. and SPECTOR Tim D., “Genetic influences on variation in female orgasmic function: a twin study", Biology Letters, vol. 1, no. 3, 2005, pp. 260-263.

FERREIRA Pedro Peixoto, "When Sound Meets Movement: Performance in Electronic Dance Music", Leonardo Music Journal, vol. 18, 2008, pp. 17-20.

FERRERI Laura, MAS-HERRERO Ernest, ZATORRE Robert J., RIPOLLÉS Pablo, GOMEZ-ANDRES Alba, ALICART Helena, olivé Guillem, MARCo-PALLARÉs Josep, ANTONIJOAN Rosa M., VALLE Marta, RIBA Jordi and RODRIGUEZ-FORNELLS Antoni, "Dopamine modulates the reward experiences elicited by music", Proceedings of the National Academy of Sciences, vol. 116, no. 9, 2019, pp. 3793-3798.

FINK Robert, “Goal-Directed Soul? Analyzing Rhythmic Teleology in African American Popular Music", Journal of the American Musicological Society, vol. 64, no. 1, 2011, pp. 179-238.

FLEISCHMAN Diana S., "An evolutionary behaviorist perspective on orgasm”, Socioaffective Neuroscience \& Psychology, vol. 6, 2016, https://www.ncbi.nlm.nih.gov/pmc/articles/ PMC5087694/.

GADIR Tami, "Forty-Seven DJs, Four Women: Meritocracy, Talent, and Postfeminist Politics", Dancecult, vol. 9, no. 1, 2017, https://dj.dancecult.net/index.php/dancecult/article/view/ $940 / 865$.

GARCIA Luis-Manuel, "Whose Refuge, This House?: The Estrangement of Queers of Color in Electronic Dance Music", MAUS Fred Everett and WHITELEY Sheila (eds.), The Oxford Handbook of Music and Queerness, Oxford University Press, 2018.

GARCIA Luis-Manuel, "On and On: Repetition as Process and Pleasure in Electronic Dance Music", Music Theory Online, vol. 11, no. 4, 2005, https://mtosmt.org/issues/mto.05.11.4/mto.

05.11.4.garcia.html.

HAWKINS Stan, "Feel the beat come down: house music as rhetoric", MOORE Allan F. (ed.), Analyzing Popular Music, Cambridge, Cambridge University Press, 2003, pp. 80-102.

HYDE Janet Shibley and DELAMATER John D., Understanding human sexuality, 6th ed., New York, NY, England, Mcgraw-Hill Book Company, 1997.

KOMISARUK Barry R. and WHIPPLE Beverly, “Non-genital orgasms”, Sexual and Relationship Therapy, vol. 26, no. 4, 2011, pp. 356-372.

LANGTON Rae, "The Impossible Necessity of 'Filling in Space”, JOHNSON Robert N. and SMITH Michael (eds.), Passions and Projections, Oxford University Press, 2015, pp. 106-115.

LAWRENCE Tim, Love Saves the Day: A History of American Dance Music Culture, 1970-1979, Durham, Duke University Press, 2004.

LODÉ Thierry, “A brief natural history of the orgasm”, All Life, vol. 13, no. 1, 2020, pp. 34-44.

VAN MAAS Sander (ed.), Thresholds of Listening: Sound, Technics, Space, Fordham University Press, 2015.

MORRIS Paul and PAASONEN Susanna, "Coming to Mind: Pornography and the Mediation of Intensity", vERnAlLIS Carol, HERZOG Amy and RICHARDSON John (eds.), The Oxford Handbook of Sound and Image in Digital Media, Oxford University Press, 2013, pp. 550-563. 
O'GRADY Alice, "Spaces of Play: The Spatial Dimensions of Underground Club Culture and Locating the Subjunctive", Dancecult, vol. 4, no. 1, 2012, pp. 86-106.

РÄÄKKÖLÄ Anna-Elena, “Sound Kink: Sadomasochistic Erotica in Audiovisual Music Performances”, University of Turku, 2016.

REYNOLDS Simon, Energy Flash: A Journey Through Rave Music and Dance Culture, Reprint edition., Berkeley, CA, Soft Skull Press, 2012.

RIETVELD Hillegonda, "Machine possession: Dancing to repetitive beats", LEVAUX C. and JULIEN O. (eds.), Over and Over: Exploring Repetition in Popular Music, New York and London, Bloomsbury Academic, 2018.

SAFRON Adam, "What is orgasm? A model of sexual trance and climax via rhythmic entrainment", Socioaffective Neuroscience \& Psychology, vol. 6, no. 1, 2016, p. 31763.

SOLBERG Ragnhild Torvanger, "'Waiting for the Bass to Drop': Correlations Between Intense Emotional Experiences and Production Techniques in Build-up and Drop Sections of Electronic Dance Music", Dancecult, vol. 6, no. 1, 2014, pp. 61-82.

ST JOHN Graham, “Technicians of Ecstasy”, соOK Nicholas, INGALLS Monique M. and TRIPPETT David (eds.), The Cambridge Companion to Music in Digital Culture, 1st ed., Cambridge University Press, 2019, pp. 168-169.

ST JOHN Graham, “The Vibe of the Exiles: Aliens, Afropsychedelia and Psyculture”, Dancecult, vol. 5, no. 2, 2013, pp. 56-87.

STRATTON Jon, “Coming to the fore: the audibility of women's sexual pleasure in popular music and the sexual revolution", Popular Music, vol. 33, no. 1, 2014, pp. 109-128.

SULLIVAN Nikki, A Critical Introduction to Queer Theory, NYU Press, 2003.

TAYLOR Jodie, "Sound Desires: Auralism, the Sexual Fetishization of Music", MAUS Fred Everett and WHITELEY Sheila (eds.), The Oxford Handbook of Music and Queerness, Oxford University Press, 2018, .

The Phenomenology of Desire and Orgasm, https://iai.tv/articles/the-phenomenology-of-orgasmand-desire-auid-1123, accessed on 31 March 2020.

THORNTON Sarah, Club Cultures Music, Media and Subcultural Capital, New York, NY, John Wiley \& Sons, 1995.

TILL Rupert, Pop cult: religion and popular music, London, New York, Continuum, 2010.

VAN REETH Adèle and NANCY Jean-Luc, Coming, First edition., New York: NY, Fordham University Press, 2017.

WEISS Margot, "Mainstreaming Kink: The Politics of BDSM Representation in U.S. Popular Media", Journal of Homosexuality, vol. 50, no. 2/3, 2006, https://wesscholar.wesleyan.edu/div2facpubs/46. WILLIAMS Linda, Screening Sex, Duke University Press, 2008.

WITEK Maria A. G., "Filling In: Syncopation, Pleasure and Distributed Embodiment in Groove: Filling In", Music Analysis, vol. 36, no. 1, 2017, pp. 138-160.

WITEK Maria A.G., "Feeling at one: Socio-affective distribution, vibe, and dance-music consciousness", Music and Consciousness 2, Oxford University Press, 2019, pp. 93-112. 


\section{NOTES}

1. https://www.youtube.com/watch?v=DoUV7Q1C1SU

2. HAWKINS Stan, "Feel the beat come down: house music as rhetoric", MOORE Allan F. (ed.), Analyzing Popular Music, Cambridge: Cambridge University Press, 2003, pp. 80-102.

3. FERREIRA Pedro Peixoto, "When Sound Meets Movement: Performance in Electronic Dance Music", Leonardo Music Journal, vol. 18, 2008, pp. 17-20.

4. ST JOHN Graham, "Technicians of Ecstasy”, cooK Nicholas, INGALLS Monique M. and TRIPPETT David (eds.), The Cambridge Companion to Music in Digital Culture, 1st ed., Cambridge University Press, 2019, pp. 168-169.

5. sт JoHn Graham, “The Vibe of the Exiles: Aliens, Afropsychedelia and Psyculture", Dancecult, vol. 5, no. 2, 2013, p. 61 .

6. MORRIS Paul and PAASONEN Susanna, "Coming to Mind: Pornography and the Mediation of Intensity", VERnAlLIS Carol, HERZoG Amy and RICHARDSON John (eds.), The Oxford Handbook of Sound and Image in Digital Media, Oxford University Press, 2013, p. 556.

7. This article does not specifically address sex clubs, many of which play similar music.

8. O'GRADY Alice, "Spaces of Play: The Spatial Dimensions of Underground Club Culture and Locating the Subjunctive", Dancecult, vol. 4, no. 1, 2012, pp. 86-106.

9. VAN REETH Adèle and NANCY Jean-Luc, Coming, First edition., New York, NY, Fordham University Press, 2017, p. 53.

10. See VAN MAAS Sander (ed.), Thresholds of Listening: Sound, Technics, Space, Fordham University Press, 2015. It is worth noting that approximately a third of participants in this study admitted to being under the influence of some sort of narcotic.

11. SAFRON Adam, "What is orgasm? A model of sexual trance and climax via rhythmic entrainment", Socioaffective Neuroscience \& Psychology, vol. 6, no. 1, 2016, p. 31763.

12. MORRIS and PAASONEN, "Coming to Mind", p. 559.

13. Ibid.

14. KOMISARUK Barry R. and WHIPPLE Beverly, "Non-genital orgasms", Sexual and Relationship Therapy, vol. 26, no. 4, 2011, pp. 356-372. Whether the ears are quite as sensitive receptors as the genitalia is perhaps subjective.

15. See WITEK Maria A.G., "Feeling at one: Socio-affective distribution, vibe, and dance-music consciousness", Music and Consciousness 2, Oxford University Press, 2019, pp. 93-112.

16. SAFRON, "What is orgasm?"

17. Ibid.

18. TILL Rupert, Pop cult: religion and popular music, London \& New York, Continuum, 2010.

19. GARCIA Luis-Manuel, "On and On: Repetition as Process and Pleasure in Electronic Dance Music", Music Theory Online, vol.11, no. 4, 2005, https://mtosmt.org/issues/mto.05.11.4/mto. 05.11.4.garcia.html ; BUTLER Mark, Unlocking the Groove: Rhythm, Meter, and Musical Design in Electronic Dance Music, Indiana University Press, 2006; wITEK Maria A. G., "Filling In: Syncopation, Pleasure and Distributed Embodiment in Groove: Filling In”, Music Analysis, vol. 36, no. 1, 2017, pp. 138-160.

20. DUNN Kate M, CHERKAS Lynn F and SPECTOR Tim D., "Genetic influences on variation in female orgasmic function: a twin study", Biology Letters, vol. 1, no. 3, 2005, pp. 260-263.

21. SOLBERG Ragnhild Torvanger, “'Waiting for the Bass to Drop': Correlations Between Intense Emotional Experiences and Production Techniques in Build-up and Drop Sections of Electronic Dance Music", Dancecult, vol. 6, no. 1, 2014, pp. 61-82.

22. LODÉ Thierry, "A brief natural history of the orgasm", All Life, vol. 13, no. 1, 2020, p. 34.

23. CHARLES Monique, "Grime and Spirit: On a Hype!", Open Cultural Studies, vol. 3, no. 1, 2019, p. 121. 
24. Thierry Lodé notes that whilst male ejaculation is the primary biological goal of intercourse, simultaneous female orgasm "increase[s] conception and progeny [...] [through] contractions that... endorse sperm retention in the female genital tract." [LODÉ Thierry, 'A brief natural history of the orgasm', All Life, vol. 13, no. 1, 2020, p. 35.]

25. Whilst Reynolds primarily discusses rave events, a lot of his findings echo the practices of nightclub participants.

26. FERRERI Laura, MAS-HERRERO Ernest, ZATORRE Robert J., RIPOLLÉs Pablo, GOMEZ-ANDRES Alba, ALICART Helena, olivé Guillem, MARCo-PALlarés Josep, ANTONiJOAn Rosa M., valle Marta, RIBA Jordi and RODRIGUEZ-FORNELLS Antoni, "Dopamine modulates the reward experiences elicited by music", Proceedings of the National Academy of Sciences, vol. 116, no. 9, 2019, pp. 3793-3798.

27. vAN MAAS (ed.), Thresholds of Listening, p. 236.

28. BANCROFt J., "The endocrinology of sexual arousal”, The Journal of Endocrinology, vol. 186, no. 3, 2005, pp. 411-427.

29. REYNOLDS Simon, Energy Flash: A Journey Through Rave Music and Dance Culture, Reprint edition., Berkeley, CA, Soft Skull Press, 2012, p. 83.

30. WiLliams Linda, Screening Sex, Duke University Press, 2008, p. 156.

31. SOLBERG, “'Waiting for the Bass to Drop"”, pp. 70-76.

32. STRATTON Jon, “Coming to the fore: the audibility of women's sexual pleasure in popular music and the sexual revolution", Popular Music, vol. 33, no. 1, 2014, pp. 109-128.

33. HYDE Janet Shibley and DELAMATER John D., Understanding human sexuality, 6th ed., New York, NY, England, Mcgraw-Hill Book Company, 1997, p. 261.

34. LANGTON Rae, "The Impossible Necessity of 'Filling in Space", JOHNSON Robert N. and SMITH Michael (eds.), Passions and Projections, Oxford University Press, 2015, p. 240.

35. The Phenomenology of Desire and Orgasm, https://iai.tv/articles/the-phenomenology-oforgasm-and-desire-auid-1123, accessed on 31 March 2020.

36. WITEK, "Filling In", p. 151.

37. FINK Robert, "Goal-Directed Soul? Analyzing Rhythmic Teleology in African American Popular Music", Journal of the American Musicological Society, vol. 64, no. 1, 2011, pp. 179-238.

38. Ibid.

39. BLINNE Kristen C, “Auto(erotic)ethnography”, Sexualities, vol. 15, no. 8, 2012, p. 955.

40. GARCIA, "On and On", p. 8.

41. Key exceptions are ambient music and noise-based genres (such as IDM industrial, glitchcore, etc.) which fall beyond the focus of this discussion.

42. RIETVELD Hillegonda, "Machine possession: Dancing to repetitive beats", LEVAUX C. and JULIEN O. (eds.), Over and Over: Exploring Repetition in Popular Music, New York and London, Bloomsbury Academic, 2018.

43. These genres are almost exclusively the domain of male producers. For more on this, see GADIR Tami, "Forty-Seven DJs, Four Women: Meritocracy, Talent, and Postfeminist Politics", Dancecult, vol.9, no.1, 2017, https://dj.dancecult.net/index.php/dancecult/article/view/ $940 / 865$.

44. SOLBERG, “'Waiting for the Bass to Drop"', p. 68.

45. https://www.youtube.com/watch?v=d1zBGT5eNVw

46. LAWRENCE Tim, Love Saves the Day: A History Of American Dance Music Culture, 1970-1979, Durham, Duke University Press, 2004, p. 233.

47. WEISS Margot, "Mainstreaming Kink: The Politics of BDSM Representation in U.S. Popular Media", Journal of Homosexuality, vol. 50, no. 2/3, 2006, p. 288, https://wesscholar.wesleyan.edu/ div2facpubs/46.

48. THORNTON Sarah, Club Cultures Music, Media and Subcultural Capital, New York, NY, John Wiley \& Sons, 1995.

Transposition, 9 | 2021 
49. BDSM Rituals: A description of a rite of passage into servitude / Slave Nano, http://slavenano.co.uk/ free-reads/bdsm-rituals-a-description-of-a-rite-of-passage-into-servitude/, accessed on 30 March 2020.

50. ST JOHN, “Technicians of Ecstasy”.

51. RIETVELD, "Machine possession".

52. CARLSTRÖM Charlotta, "BDSM, Interaction Rituals and Open Bodies”, Sexuality \& Culture, vol. 22, no. 1,2018 , p. 217.

53. РÄÄKKÖLÄ Anna-Elena, "Sound Kink: Sadomasochistic Erotica in Audiovisual Music Performances", University of Turku, 2016, p. 209.

54. TILL, Pop cult.

55. FLEISCHMAN Diana S., "An evolutionary behaviorist perspective on orgasm", Socioaffective Neuroscience \& Psychology, vol.6, 2016, https://www.ncbi.nlm.nih.gov/pmc/articles/ PMC5087694/.

56. MORRIS and PAASONEN, "Coming to Mind", p. 557.

57. Ibid.

58. TAYLOR Jodie, "Sound Desires: Auralism, the Sexual Fetishization of Music", MAUS Fred Everett and WHITELEY Sheila (eds.), The Oxford Handbook of Music and Queerness, Oxford University Press, 2018; See also DENORA Tia, "Music and Erotic Agency - Sonic Resources and Social-Sexual Action", Body \& Society, 2016, https://journals.sagepub.com/doi/10.1177/1357034X97003002004.

59. GARCIA Luis-Manuel, "Whose Refuge, This House?: The Estrangement of Queers of Color in Electronic Dance Music", maus Fred Everett and wHITELEY Sheila (eds.), The Oxford Handbook of Music and Queerness, Oxford University Press, 2018.

60. Burning Down the House: Read SPIN's 1986 Feature on Chicago's Club Scene / SPIN, https:// www.spin.com/2014/04/burning-down-the-house-chicago-club-80s/, accessed on 25 March 2020. 61. GARCIA, "Whose Refuge, This House?", p. 18.

62. SULLIVAN Nikki, A Critical Introduction to Queer Theory, NYU Press, 2003, p. 168.

\section{ABSTRACTS}

Portrayals of sexualized narratives are rife in ethnographic accounts of Electronic Dance Music (EDM), where the visceral musical and haptic experiences of dancing to club music are intertwined in a tantalizing symbiosis. This is music that is habitually understood through erotic semiosis: protracted build ups of stimulation and intensity, layer upon layer of musical repetition being added in service of arousal, and a teasing denial of harmonic and sonic resolution are expanded and amplified, until there is a final fulfilment granted by the DJ at the moment of the "drop". Bringing together musicological discussions of climax with socio-psychological and neurological research on the orgasm, this article explores the manifold ways in which technologies of arousal in dance music mediate the sexual space of the dancefloor and consider how metaphors of pleasure and fulfilment are actualised in EDM in ways which destabilise the prevalent body of heteronormative, male-focussed narratives around stimulation and arousal.

Les récits sexualisés sont fréquents dans les approches ethnographiques de l'Electronic Dance Music (EDM), où en dansant au son de la musique les expériences musicales et haptiques ressenties de manière viscérale se mélangent dans une symbiose fascinante. Cette musique est 
souvent comprise en termes d'une sémiosis érotique, à savoir comme de longues progressions de stimulation et d'intensité, où des couches musicales répétitives se superposent au service de l'excitation, et où la résolution harmonique et sonore est refusée de manière aiguichante jusqu'à ce que la satisfaction finale soit déclenchée par le DJ au moment du "drop". En croisant des contributions musicologiques sur le climax et des recherches socio-psychologiques et neurologiques sur l'orgasme, cet article explore comment les technologies de l'excitation de la dance music médiatisent l'espace sexuel du dancefloor. Il se penche sur comment les métaphores du plaisir et la satisfaction s'actualisent dans l'EDM de manière à déstabiliser le corpus dominant, focalisé sur l'expérience masculine, de récits hétéronormatifs sur la stimulation et l'excitation.

\section{INDEX}

Mots-clés: EDM, orgasme, drop, climax, répétition, extase

Keywords: EDM, orgasm, drop, climax, repetition, ecstasy

\section{AUTHOR}

\section{TOBY YOUNG}

Dr Toby Young is composer and researcher who draws on popular musicology, philosophy, and cultural sociology to examine the blurred space between classical and popular music. He is currently a Leverhulme Early Career Fellowship at the Guildhall School of Music and Drama, following three years as Gianturco Junior Research Fellow in Music and Philosophy at Linacre College, Oxford, with a project focusing on the interaction between dance music and beauty. Toby has given numerous public talks and lectures, including a TEDx talk, a series of three radio programmes on 'Artistic Knowledge' for Resonance FM, talks on the creative process and music industry for Saïd Business School, and a lecture on beauty and taste for Gresham College. As an award-winning composer, Toby has written for artists including the Rolling Stones, Duran Duran, the London Symphony Orchestra, Chase \& Status, the choir of Westminster Abbey and Jacob Banks. 